Kalpa Publications in Civil Engineering
Volume 1, 2017, Pages 80-86
$\begin{gathered}\text { ICRISET2017. International Conference on Re- } \\ \text { search and Innovations in Science, Engineering } \\ \text { \&Technology. Selected papers in Civil Engineering }\end{gathered}$

\title{
Experimental Studies on Rheological and Durability Properties of Self Compacted Concrete by Using Quaternary Blending
}

\author{
Ashika Shah ${ }^{1,}$ Indrajit Patel ${ }^{2}$, Jagruti Shah $^{3}$, Gaurav Gohil ${ }^{4}$ \\ ${ }^{1}$ Structural Engineer, Vapi, ashika9shah@gmail.com \\ ${ }^{2}$ Professor, BVM Engineering College, V V Nagar, inpate134@gmail.com \\ ${ }^{3}$ Research Scholar, GTU Ahmedabad \\ ${ }^{4}$ Assistant Professor, SPCE, Anand gohilgaurav534@gmail.com
}

\begin{abstract}
In the production of Self Compacting concrete (SCC), the use of quaternary blend of supplementary cementitious materials (SCM's) has not found enough applications. For this purpose, an effort has been done to present a mix design for M60 grade and M80 grade SCC with quaternary blending of fly ash(FA), ground granulated blast furnace slag(GGBS), silica fume (SF) in accordance with EFNARC guidelines. Findings: In this study, cement has been replaced with SCM's from $30 \%$ to $50 \%$. Fresh properties of concrete were tested for slump flow, T50 test and U box. The hardened properties of concrete were tested for compressive strength and durability. The tests were performed for 7, 28, 56 and 91 days. The results indicate that the use of quaternary blend has improved the workability, compressive strength and durability properties of specimens than the control specimen. Application: The primary contribution is to fill the congested reinforcement and increase the durability and life span of the structure.

Keywords: -Self Compacting concrete (SCC), Fly Ash, GGBS, silica fume, durability.
\end{abstract}

\section{Introduction}

SCC is a concrete which flows under its own weight without the need of external vibrator. Due to resistance to segregation and high fluidity it is able to pumped to longer distance and it is not affected by type of reinforcement bars and labor skills. Even if there is congested reinforcement it can fill the voids, and spaces. Clear difference is there between the normal concrete and SCC. The SCM's include FA, GGBS, SF. SCC requires high proportions of SCM's and incorporation of super plasticizer. The SCM's are added to the concrete to enhance the properties of the concrete, and also to improve the mechanical strength, durability and reduce the environmental impact. Now a days, SCC is getting more attention by researchers due to the various construction problems such as inconsistent construction quality, reduce in the durability and life span of the structure, noise 
pollution due to vibration of equipment, increase cost of labor and materials, inadequate compaction in congested reinforcement, inadequate compaction leads to large number of voids which can reduce the strength and durability of the structures. To overcome these problems special concrete known as Self Compacting Concrete (SCC) is developed. The main reasons for employment of SCC are to shorten the time period, to eliminate the noise during vibration, to ensure compaction of structures even in congested reinforcement. To achieve SCC it should meet the following needs its filling ability, passing ability and resistance to segregation during placing and transportation. The disadvantage of the SCC is no codes are available for the mix design and cost is slightly higher than normal concrete. This research work mainly emphasis on the engineering and durability criteria of SCC using partial replacement of SCM's in the concrete.

\section{Material properties}

The properties of the materials which were used in this research are as follow Cement: - 53 grade OPC cement is used. The properties of cement are confirmed to IS 12269-2013.Fine aggregate: locally available river sand is used. Sieve analysis has been carried out. The results were as per IS 383-1970. River sand is of Zone II. The specific gravity and fineness modulus of the sand is 2.58 and 2.83.Coarse aggregate:- Natural aggregate of size $10 \mathrm{~mm}$ and $20 \mathrm{~mm}$ are used. The aggregate were tested and sieve analysis has been confirmed to IS 2386(Part 1,2,3). The specific gravity and fineness modulus of coarse aggregate is 2.88 and 6.02.Chemical admixture: - To reduce the water cement ratio admixture, Sika viscrocrete 2044 is used. The dosage of admixture has been decided by marsh cone test. Water:- Fresh water with PH 6.68 is used for casting and curing.

\begin{tabular}{cccc}
\hline Properties & Silica fume & GGBS & Fly ash \\
\hline $\begin{array}{c}\text { Fineness or surface } \\
\text { area }\end{array}$ & 750.16 & 395 & 333 \\
\hline Loss on ignition & $1.04 \%$ & 0.65 & 0.87 \\
\hline Moisture & $0.10 \%$ & 0.38 & 0.132 \\
\hline $\begin{array}{c}\text { Passing on 45 } \\
\text { Micron sieve (Wet } \\
\text { sieving) }\end{array}$ & $99.20 \%$ & - & - \\
\hline $\begin{array}{c}\text { Retention on 45 Micron } \\
\text { sieve (Wet sieving) }\end{array}$ & $0.8 \%$ & & \\
\hline Specific Gravity & 2.3 & 2.90 & 3.5 \\
\hline
\end{tabular}

\section{Table 1 Physical Properties of materials}




\section{Experimental programme}

SCC mix proportions

By conducting various trial mix designs final trial mix has been designed. It satisfied EFNARC guidelines for SCC. Table 1 shows the final mix proportions of each SCC with different percentage of fly ash, GGBS and silica fume. The water cement ratio is 0.28 for $\mathrm{M}$ 60 and 0.22 for M 80.

\begin{tabular}{|c|c|c|c|c|c|c|c|c|c|}
\hline $\begin{array}{c}\text { Design } \\
\text { mix }\end{array}$ & $\begin{array}{c}\text { OPC } \\
\underset{3}{\mathrm{Kg} / \mathrm{m}}\end{array}$ & $\begin{array}{c}\text { GGBS } \\
\mathrm{Kg} / \mathrm{m}^{3}\end{array}$ & $\begin{array}{c}\text { FA } \\
\mathrm{Kg} / \mathrm{m}^{3}\end{array}$ & $\begin{array}{c}\mathrm{SF} \\
\mathrm{Kg} / \mathrm{m}^{3}\end{array}$ & $\begin{array}{c}\text { Fine } \\
\text { aggregate } \\
\mathrm{Kg} / \mathrm{m}^{3}\end{array}$ & \multicolumn{2}{|c|}{$\begin{array}{c}\text { Coarse } \\
\text { aggregate } \\
\mathrm{Kg} / \mathrm{m}^{3}\end{array}$} & \multirow[t]{2}{*}{$\begin{array}{c}\text { Water } \\
\text { Lit }\end{array}$} & \multirow[t]{2}{*}{$\begin{array}{c}\text { SP } \\
\text { Lit } / \mathrm{m}^{3}\end{array}$} \\
\hline $\begin{array}{c}\text { For } \\
\text { M60 }\end{array}$ & & & & & & $10 \mathrm{~mm}$ & $\begin{array}{c}20 \mathrm{~m} \\
\mathrm{~m}\end{array}$ & & \\
\hline A0 & 530 & - & - & - & 661 & 457 & 635 & 174 & 3.7 \\
\hline A1 & 265 & 106 & 106 & 53 & 661 & 457 & 635 & 174 & 3.7 \\
\hline A2 & 235 & 133 & 106 & 53 & 661 & 457 & 635 & 174 & 3.7 \\
\hline A3 & 212 & 133 & 133 & 53 & 661 & 457 & 635 & 174 & 3.7 \\
\hline A4 & 159 & 159 & 159 & 53 & 661 & 457 & 635 & 174 & 3.7 \\
\hline \multicolumn{10}{|c|}{ For M80 } \\
\hline B0 & 620 & - & - & - & 558 & 458 & 684 & 180 & 4.3 \\
\hline B1 & 310 & 124 & 124 & 62 & 558 & 458 & 684 & 180 & 4.3 \\
\hline B2 & 279 & 124 & 155 & 62 & 558 & 458 & 684 & 180 & 4.3 \\
\hline B3 & 248 & 155 & 1555 & 62 & 558 & 458 & 684 & 180 & 4.3 \\
\hline B4 & 186 & 186 & 186 & 62 & 558 & 458 & 684 & 180 & 4.3 \\
\hline
\end{tabular}

Table 2 Mix Proportion

\section{Results and Discussions}

4.1 Rheological properties 
To ensure the SCC, workability test is carried out. Slump flow, T50 flow and U box are conducted immediately after the fresh mix formed. The procedure of the test was conducted as per the guidelines EFNARC. The slump value was in the range of $652 \mathrm{~mm}$ to $710 \mathrm{~mm}$ for M60 grade concrete and $670 \mathrm{~mm}$ to $720 \mathrm{~mm}$ for M80 grade concrete which was acceptable by the guidelines. The T50 test was 2.4-2.45 sec for M60 grade concrete and 2.5- 2.7 second for

M80 grade concrete which was acceptable as per the guidelines it was 2-5 seconds. The U box test was also satisfying the SCC criteria.

\begin{tabular}{|c|c|c|c|c|}
\hline Design Mix & Proportions & Slump flow & T50 Test & U box Test \\
\hline For M60 & $\mathrm{FA}+\mathrm{GGBS}+\mathrm{SF}$ & & & \\
\hline A0 & $0 \%$ & 652 & 2.3 & 20 \\
\hline A1 & $\begin{array}{c}20 \%+20 \%+1 \\
0 \%\end{array}$ & 685 & 2.35 & 24 \\
\hline A2 & $\begin{array}{c}20 \%+25 \%+1 \\
0 \%\end{array}$ & 710 & 2.2 & 27 \\
\hline A3 & $\begin{array}{c}25 \%+25 \%+1 \\
0 \%\end{array}$ & 675 & 2.4 & 25 \\
\hline A4 & $\begin{array}{c}30 \%+30 \%+1 \\
0 \%\end{array}$ & 660 & 2.45 & 22 \\
\hline \multicolumn{5}{|c|}{ For M80 } \\
\hline B0 & $0 \%$ & 670 & 2.3 & 25 \\
\hline B1 & $20 \%+20 \%+10 \%$ & 690 & 2.35 & 27 \\
\hline B2 & $20 \%+25 \%+10 \%$ & 720 & 2.2 & 28 \\
\hline B3 & $25 \%+25 \%+10 \%$ & 695 & 2.4 & 26 \\
\hline B4 & $30 \%+30 \%+10 \%$ & 685 & 2.45 & 25 \\
\hline
\end{tabular}

\section{Table 3 Workability Test}

Slump flow of M60 grade concrete was carried out and it satisfies the slump test criteria. The slump flow was $710 \mathrm{~mm}$. According to the EFNARC, the mix design satisfy all the requirements and all under the acceptable criteria. 


\subsection{Durability properties}

\subsubsection{Water Permeability Test}

\begin{tabular}{cccc}
\hline $\begin{array}{c}\text { Sr } \\
\text { No }\end{array}$ & $\begin{array}{c}\text { Mix } \\
\text { Type }\end{array}$ & $\begin{array}{c}\text { \% of FLY-ASH } \\
\text { +GGBS+ } \\
\text { SILICA FUME }\end{array}$ & $\begin{array}{c}\text { Water } \\
\text { permeability } \\
\text { Test } \\
(\mathbf{m m})\end{array}$ \\
\hline $\mathbf{1 .}$ & AO & $0 \%$ & 5.0 \\
\hline $\mathbf{2 .}$ & A1 & $\begin{array}{c}20 \%+20 \%+10 \\
\%\end{array}$ & 4.1 \\
\hline 3. & A2 & $\begin{array}{c}20 \%+25 \%+10 \\
\%\end{array}$ \\
\hline 4. & A3 & $\begin{array}{c}25 \%+25 \%+10 \\
\%\end{array}$ & 3.8 \\
\hline $\mathbf{5 .}$ & A4 & $\begin{array}{c}30 \%+30 \%+10 \\
\%\end{array}$ \\
\hline
\end{tabular}

Table 4 Water Permeability test for M60 Grade Concrete

\begin{tabular}{cccc}
\hline $\begin{array}{c}\text { Sr } \\
\text { No }\end{array}$ & $\begin{array}{c}\text { Mix } \\
\text { Type }\end{array}$ & $\begin{array}{c}\text { \% of FLY-ASH } \\
\text { +GGBS+ } \\
\text { SILICA FUME }\end{array}$ & $\begin{array}{c}\text { Water } \\
\text { permeability } \\
\text { Test }\end{array}$ \\
\hline $\mathbf{1 .}$ & BO & $0 \%$ & 4 \\
\hline $\mathbf{2 .}$ & B1 & $\begin{array}{c}20 \%+20 \%+10 \\
\%\end{array}$ & 3.1 \\
\hline $\mathbf{3 .}$ & B2 & $\begin{array}{c}20 \%+25 \%+10 \\
\%\end{array}$ & 2.8 \\
\hline $\mathbf{4 .}$ & B3 & $\begin{array}{c}25 \%+25 \%+10 \\
\%\end{array}$ & 2.9 \\
\hline $\mathbf{5 .}$ & B4 & $\begin{array}{c}30 \%+30 \%+10 \\
\%\end{array}$ & 3.0 \\
\hline
\end{tabular}

Table 5 Water Permeability test for M60 Grade concrete

\subsubsection{Carbonation depth}

Carbonation test obtained by various combination of fly ash, GGBS and Silica Fume for M60 and M80 grade concrete is as shown

Table 6 Carbonation Test for M60 Grade of concrete

\begin{tabular}{cccc}
\hline Sr & Mix & \% of FLY-ASH & Carbonation \\
No & Type & +GGBS+ & Test \\
& & SILICA FUME & \\
\hline
\end{tabular}




\begin{tabular}{cccc}
\hline 1. & AO & $0 \%$ & 19.7 \\
\hline 2. & A1 & $\begin{array}{c}20 \%+20 \%+10 \\
\%\end{array}$ & Nil \\
\hline 3. & A2 & $\begin{array}{c}20 \%+25 \%+10 \\
\%\end{array}$ & Nil \\
\hline 4. & A3 & $\begin{array}{c}25 \%+25 \%+* 1 \\
0 \%\end{array}$ & Nil \\
\hline $\mathbf{5 .}$ & A4 & $30 \%+30 \%+10$ & Nil \\
& & $\%$ &
\end{tabular}

Table 6 Carbonation Test for M60 grade concrete

\begin{tabular}{cccc}
$\begin{array}{c}\text { Sr } \\
\text { No }\end{array}$ & $\begin{array}{c}\text { Mix } \\
\text { Type }\end{array}$ & $\begin{array}{c}\text { \% of FLY-ASH } \\
\text { +GGBS+ } \\
\text { SILICA FUME }\end{array}$ & $\begin{array}{c}\text { Carbonation } \\
\text { Test }\end{array}$ \\
\hline 1. & BO & $0 \%$ & 14.5 \\
\hline $\mathbf{2 .}$ & B1 & $\begin{array}{c}20 \%+20 \%+10 \\
\%\end{array}$ & Nil \\
\hline 3. & B2 & $\begin{array}{c}20 \%+25 \%+10 \\
\%\end{array}$ & Nil \\
\hline 4. & B3 & $\begin{array}{c}25 \%+25 \%+10 \\
\%\end{array}$ & Nil \\
\hline 5. & B4 & $\begin{array}{c}30 \%+30 \%+10 \\
\%\end{array}$ & Nil \\
\hline
\end{tabular}

Table 7 Carbonation Test for M80 grade concrete

\subsubsection{Mercury Porosity Test}

\begin{tabular}{cc}
\hline Sample mass $(\mathrm{gm})$ & $\mathbf{1 . 5 4 6}$ \\
\hline Sample Density $(\mathrm{g})$ & 1 \\
\hline Mercury height $(\mathrm{mm})$ & 27.666 \\
\hline Volume at run $\left(\mathrm{mm}^{3}\right)$ & 471 \\
\hline $\begin{array}{c}\text { Weight of dilatometer }+ \text { mercury }+ \\
\text { sample }(\mathrm{g})\end{array}$ & 231.955 \\
\hline Capillary mercury height $(\mathrm{mm})$ & 0.666
\end{tabular}

Table 8 Mercury Porosity test input data

\begin{tabular}{cc}
\hline Total cumulative volume $(\mathrm{cc} / \mathrm{g})$ & $\mathbf{0 . 4 1}$ \\
\hline Total specific surface $\operatorname{area}\left(\mathrm{m}^{2} / \mathrm{g}\right)$ & 8.94 \\
\hline Average pore diameter (Micron) & 0.1829 \\
\hline
\end{tabular}




\begin{tabular}{cc}
\hline Total porosity $(\%)$ & 5.768 \\
\hline Bulk density $\left(\mathrm{g} / \mathrm{cm}^{3}\right)$ & 1.40821 \\
\hline Apparent density $\left(\mathrm{g} / \mathrm{cm}^{3}\right)$ & 1.49441 \\
\hline Sample volume correction & 0.9401875
\end{tabular}

Table 9 Mercury Porosity test output data

The Mercury porosity test analyses the pore size and pore diameter and void space between the particles. Results interpret that the total porosity of mercury intrusion is $5.768 \%$, which means very low permeable.

\section{References}

PL Domone, HW .Chai, J. Jin, Optimum mix proportioning of self-compacting concrete Sedran, T., De Larrard, Optimization of self-compacting concrete thanks to packing model, Proceedings of the 1st International RILEM symposium on self-compacting concrete, Sweden, (1999), pp 321-332.

PUJA SAIKIA, International Journal of Engineering Research-Online A Peer Reviewed International Journal Articles available online http://www.ijoer.in Vol.3., Issue.4., 2015 (July-Aug).

Rita M. Rathod "To study the effect of varying proportion of Fly Ash and Silica Fume on Fresh and Mechanical Properties of High Strength Self Compacting Concrete". IJISET International Journal of Innovative Science, Engineering \& Technology, Vol. 2 Issue 7, July 2015. 